\title{
INFORMÁCIÓS RENDSZEREK SZEREPE A FORGÁCSOLÁSI ADATOK MEGHATÁROZÁSÁNÁL
}

\author{
Vajda Gyula
}

\section{Összefoglalás}

A technológiai tervezésben az optimális forgácsolási paraméterek meghatározása rendkivüli jelentơségá. Az üzemi célokat és a gazdaságossági szempontokat kielégító technológiai adatok helyes megválasztása a gyártáselơkészités fontos feladata. Az 1960-as évektől kezdర̋dően a forgácsolás területén a szerszámgépek, szerszámok, szerkezeti anyagok, megmunkálási módozatok tekintetében végbemenర్ nagymértéku fejlödés hatására olyan nagy mennyiséga adathalmaz áll a gyártástervezơk rendelkezésére, amely szükségessé teszi az adatfeldolgozás automatizálását. A számítógépek és számítógépes hálózatok elterjedésével fokozatosan épitettek ki információs rendszereket. A technológiai információs rendszerek mưkődésének feltétele a forgácsolási adatok számitásához szưkséges alapadatok ơsszegyưjtése, képzése, egységesitése, kezelése, karbantartása - számítógéppel kezelhetơ adatbázissá szervezése. A kiépitett adatbázisra támaszkodva, a kiđolgozott külơnbơzơ módszerek, számitógépi programok, optimáló eljárások segítségével végzik - a felhasználói igényeknek megfelelớen - a szolgáltatásokat. A cikk az adatbankok rendeltetését, osszetevơit és mưkơdési mechanizmusát foglalja ossze. Részletesebben foglalkozik az adatmeghatározás alapjảul szolgáló matematikai modell felépitésével.

\section{Bevezetés}

A gépiparban a megmunkáló gépek megjelenése óta örökös törekvés a termelékenység növelése. A mechanikus automaták kifejlesztése révén az 1950-es évekig az automatizálás igen magas szintet ért el. Ezek legnagyobb hátránya, hogy gazdaságosan csak nagysorozat- és tömeggyártás esetén voltak alkalmazhatók.

A számjegyes vezérlés megjelenésével, majd a számítástechnika gépgyártástechnológiai alkalmazásának fejlesztésével létrejöttek a DNC, CNC gyártórendszerek és megkezdődött a számitógéppel vezérelt integrált gyártórendszerek kialakítása. $\mathrm{E}$ gépek magas ára miatt maximális kihasználtságra kellett törekedni. Ez a gyártástervezés sok más tényezōje mellett a technológiai tervezés korszerũsitését is igényelte. Felismerték, hogy a technológiai tervezésen belül a forgácsolási adatok helyes megválasztásának milyen nagymértékũ gazdasági jelentősége van.

A problémát az jelentette, hogy a szerszámgépek, szerszámok, szerkezeti anyagok választékának fokozatos és erôteljes bổülésével olyan nagy mennyiségũ - a forgácsolási folyamat optimálásához szükséges - adat halmozódott fel, amelynek kezelését egy-egy vállalat már nem volt képes elvégezni.

\section{Technológiai információs rendszerek}

Az iparilag fejlett országokban technológiai információs rendszereket - adatbankokat - építettek ki, amelyek gyüjtik, kezelik, rendszerezik és ōsszefuggô adatbázissá szervezik a forgácsolási folyamat mưszaki és gazdasági paramétereit, elōállítják és gondozzák a technológiai folyamat tervezésére, az adatok 
optimálására szolgáló számitógépes rendszereket, és az ipart ellátják megfelelō, lehetōleg optimális technológiai és gazdasági adatokkal, számitási eljárásokkal. Az adatbankok mũködési folyamatának fôbb lépéseit az 1 . ábra szemlélteti.

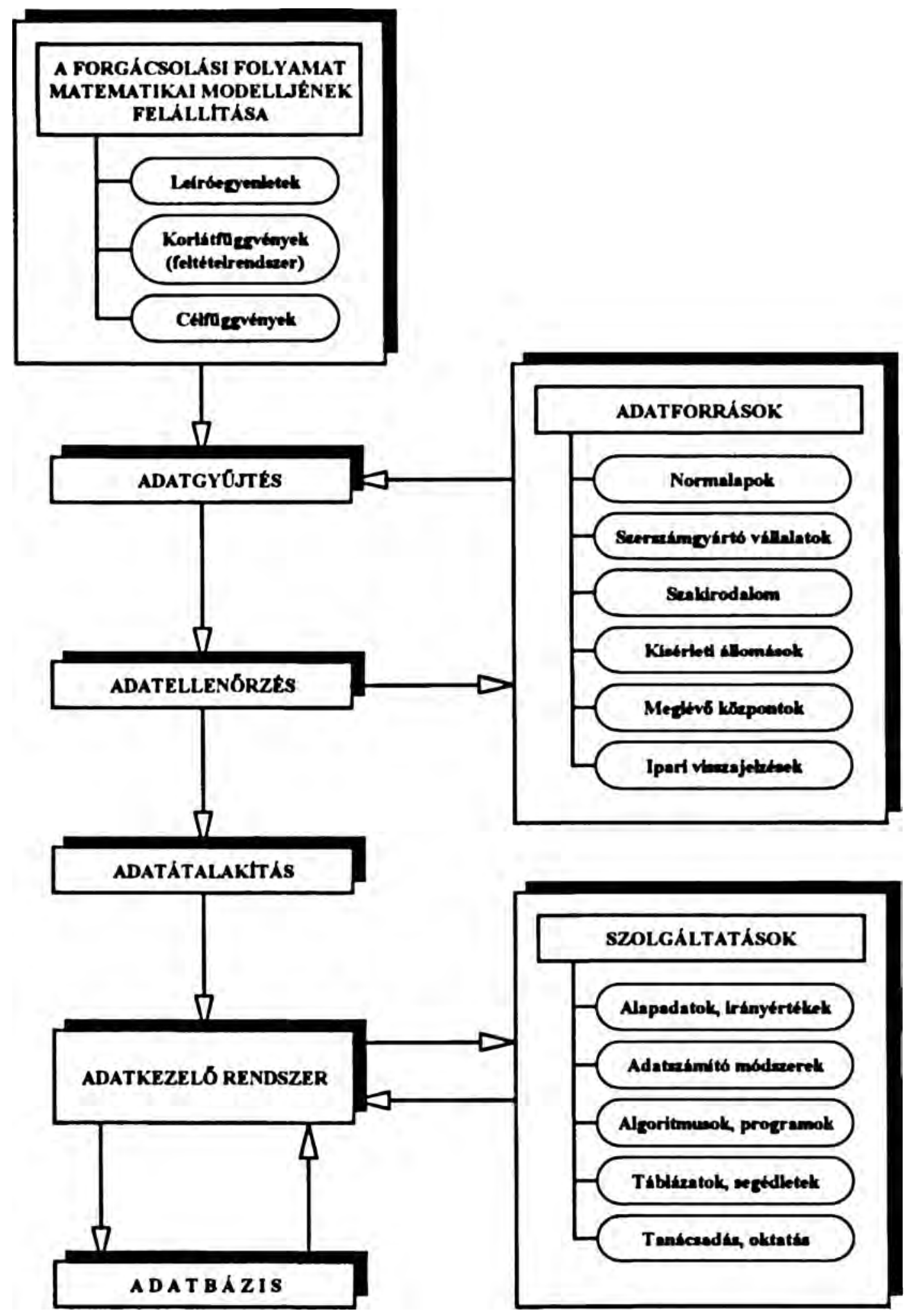

1. ábra

Az adatbankok munkafolyamata 


\section{A forgácsolási folyamat matematikai modellje}

Az adatbankokban az optimális adatok képzése ún. matematikai modell segitségével történik. A matematikai modell elemeit az 1 . táblázat mutatja be.

A matematikai modell elemei

1. táblázat

\begin{tabular}{|c|c|c|}
\hline Leíróegyenletek & Feltételrendszer & Célfüggvények \\
\hline $\begin{array}{l}\text { - éltartam függvények } \\
\text { - erỏ képletck } \\
\text { - kopás függvények } \\
\text { - érdességi összefüggések } \\
\text { - pontossági összefuggések } \\
\text { - hốmérséklet képletek } \\
\text { - }\end{array}$ & $\begin{array}{l}\text { - szerszám } \\
\text { - munkadarab és anyaga } \\
\text { - szerszámgép } \\
\text { - készülék } \\
\text { - forgácsolási folyamat } \\
\text { - }\end{array}$ & $\begin{array}{l}\text { - min. költség } \\
\text { - max. termelékenység } \\
\text { - elöbbiek kompromisszuma } \\
\text { - legnagyobb nyereség } \\
\text { - legkisebb főidõ } \\
\text { - }\end{array}$ \\
\hline
\end{tabular}

\subsection{Leíróegyenletek}

A forgácsolás paraméterei között a leiróegyenletek teremtenek kapcsolatot. Segitségükkel határozhatók meg a forgácsolási folyamat mechanikai, kopás- és pontossági jjellemzôi. A leiróegyenletek közül kiemelt fontosságú az éltartamösszefuggés, mivel ez az optimálás egyik alapösszefüggése.

\subsection{Feltételrendszer és korlátfiiggvények}

A korlátozó tényezở határolják be az alkalmazható technológiai paraméterek tartományát. A technológiai paraméterek korlátai a korlátfuggvényekkel számszerüsithetôk. A korlátfüggvények összessége a matematikai modell feltételrendszere. A 2. táblázat egy CBN szerszámmal esztergálásra kidolgozott matematikai modell feltételrendszerét tartalmazza.

\subsection{Célfüggvények és optimálás}

A forgácsolási folyamat olyan technológiai paraméterek mellett optimális, amelyek alkalmazásával a kitũzött cél a legjobban megközelithetō. A cél leggyakrabban a legkisebb költség vagy a legnagyobb termelékenység (legkisebb megmunkálási idô). A kitũzött célok - optimumfeltételek - megfogalmazhatók matematikai összefüggések formájában is, ezek az optimálás célfüggvényei. A feltételrendszer, az éltartamösszefuggés és az optimumkritérium alapján egy kiválasztott optimáló eljárás alkalmazásával történhet meg a technológiai adatok meghatározása.

\section{Adatkezelés}

A matematikai modell függvényei a forgácsolási paramétereken kivül nagyszámú állandót is tartalmaznak. Az adatbank müködéséhez elengedhetetlen, hogy megfelelō mennyiségũ alapadat álljon rendelkezésre a további adatok származtatásához. Ezeket az alapadatokat megbizható forrásokból kell összegyüjteni. Az adatgyüjtést követi az adatellenōrzés, ami a beérkezỏ adatok formai, tartalmi és mennyiségi hibáinak felderítésébõl áll. Az ellenōrzött adatokat egységesitik, és a számitógépes adatfeldolgozás követelményeinek megfelelōen átalakitják, csoportositják. Végül az adatkezelō rendszer irányitásával adatbázisban kerülnek tárolásra, illetve további felhasználásra. 


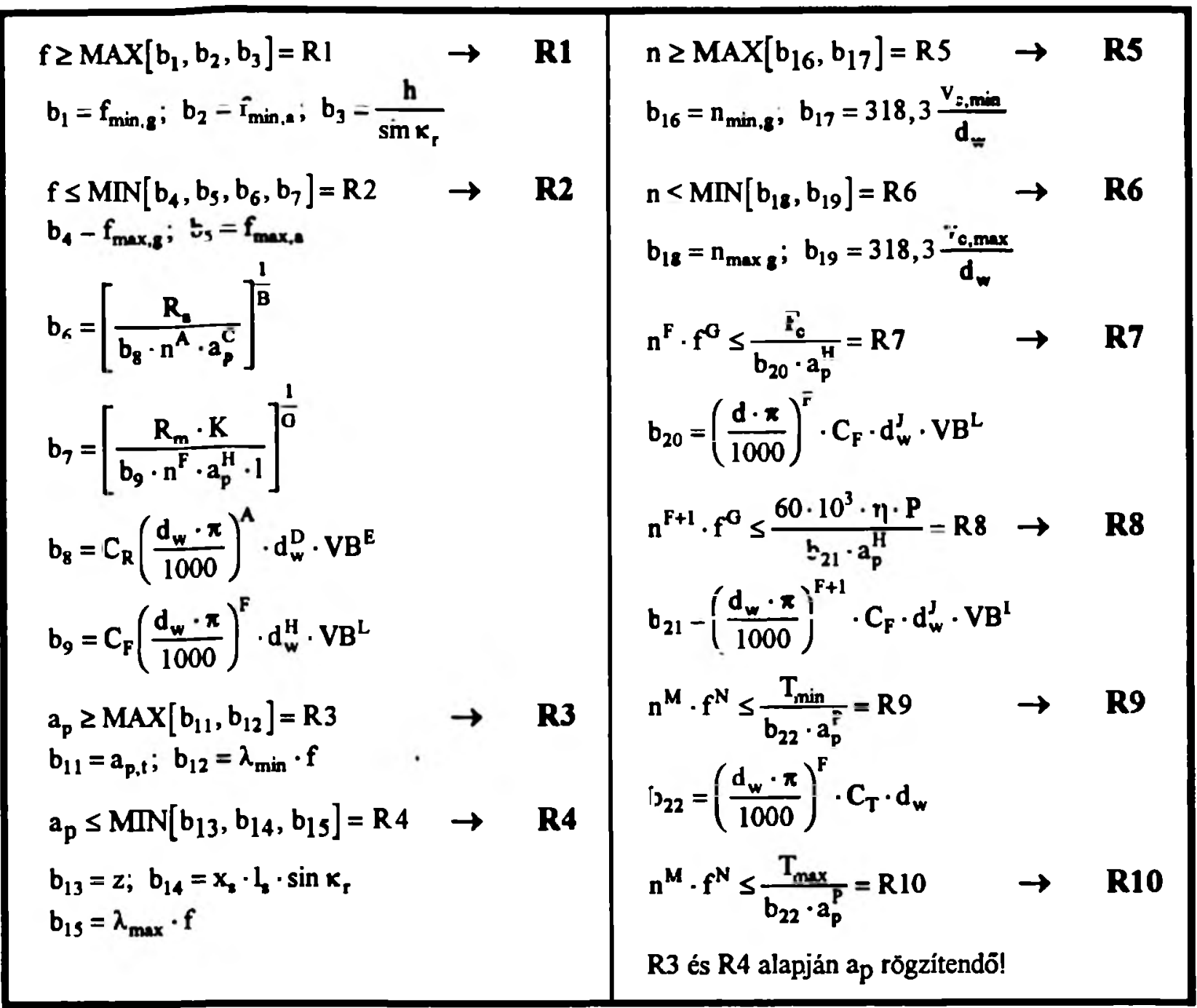

\section{Irodalom:}

[1] J. KUNDRÁK, K. GYÁN, GY. VAJDA: Problems of mathematical modelling in data banks to be set up for superhard tools. microCAD '94, Kharkov, 1994. május 3-5. pp. 70-73.

[2] GYÁNI K., KUNDRÁK J.: A forgácsoló megmunkálás matematikai modellje. Technológiai információs rendszer elméleti megalapozása határozott élü szuperkemény szerszámokkal végzett forgácsoláshoz IV/6. OTKA T4261. Témavezetô: Dr. Kundrák János. Miskolc, 1993. p. 33.

[3] J. KUNDRAK, K. GYÁNI, GY. VAJDA: Some questions of cutting data concerning to superhard tools. Interpartner '94, Alusta, sept. 28 - okt. 2. 1994. pp. 126-131.

\section{Vajda Gyula, doktorandusz}

Miskolci Egyetem, H-3515 Miskolc-Egyetemváros

Gépgyártástechnológiai Tanszék

Tel: 36-46-365 111/15-83; Fax: 36-46-364 941

E-mail: ggytvgy@gold.uni-miskolc.hu 